\title{
DETERMINING THE BEST \\ INTERESTS OF THE CHILD \\ IN CUSTODY BATTLES: \\ SHOULD A CHILD'S VOICE \\ BE CONSIDERED?*
}

\author{
Frans Mashilo Mahlobogwane \\ BProc LLB LLM \\ Senior Lecturer, Department of Jurisprudence \\ University of South Africa (UNISA)
}

SUMMARY

South African courts and other Commonwealth Courts have long emphasized the notion that "best interests" of a child plays a significant role in custody decisions. When the court decides any question with respect to a child's upbringing, it is under the duty to have regard to the ascertainable wishes and feelings of the child concerned. The weight to be given to the wishes and feelings has to be ascertained according to the child's age or understanding. However, courts still face a complex task when having to determine the best interests of a child, for there is no easy way of establishing what these rights are. Most of the children who find themselves at the centre of custody battles suffer the long-term and short-term stresses of divided loyalty.

This paper will look at the following challenging questions: whether children are entitled to be consulted in major decisions affecting their custody, are children given any means of making their views known to the court, to what extent should a child's view be considered, should those views be the only decisive factor.

INTRODUCTION

As is often the nature of custody disputes, decisions about which parent to reside with after the parents' divorce have enormous repercussions for children. ${ }^{1}$ This repercussions reverberate into adulthood. There are therefore

Revised version of a paper presented at "Children and the Law: International Approaches to Children and their Vulnerabilities" Conference, Monash University Centre, Prato, Italy 7-10 September 2009. The author wishes to thank with gratitude Prof JM Kruger, University of South Africa and Prof E Bonthuys, University of Witwatersrand for their useful comments on an earlier draft.

1 Burman The Fate of the Child: Legal Decisions on Children in the New South Africa (2003) 145. S 1(1)(g) of the Children's Act 38 of 2005 defines a child as "a person under the age of 18". Article 1 of the Convention on the Rights of the Child of 1989 defines a child as "a person below the age of 18 , unless the relevant laws recognize an earlier age of majority". 
several provisions giving children the right to make their own decisions while they are still minors. ${ }^{2}$

In family law, the central principle relating to children is that any decision made should be in the best interest of the child. The Convention on the Rights of the Child provides that the best interests of the child must be a primary consideration in all actions concerning that child. ${ }^{3}$ The preamble to the Convention emphasizes the role of the family in the life of the child. It determines as follows

"it re-affirms the fact that children, because of their vulnerability need special care and protection, and it places special emphasis on the primary caring and protective responsibility of the family. It also re-affirms the need for legal and other protection of the child before and after birth, the importance of respect for the cultural values of the child's community, and the vital role of international co-operation in securing children's rights". ${ }^{4}$

South African courts are compelled to place particular emphasis on the best interests of the child, not only because of their role as upper guardian of all minors ${ }^{5}$ but also because of the provisions of section 28(2) of the Constitution of the Republic of South Africa, 1996, which provides that "[a] child's best interests are of paramount importance in every matter concerning the child". ${ }^{6}$ What transpires from the judgements is that what is best for a specific child or children cannot be determined with absolute certainty. ${ }^{7}$

Questions often arise as to whether a child's views should be taken into account by the court in determining the question of custody. ${ }^{8}$ The writer will

In these respects, children need not be represented by a guardian.

3 Article 3(1) provides that "In all actions concerning children, whether undertaken by public or private social welfare institutions, courts of law, administrative authorities or legislative bodies, the best interests of the child shall be a primary consideration."

4 UNICEF, Convention on the Rights of the Child adopted by the UN General Assembly in 1989. As a signatory of the Convention, South Africa currently has a moral obligation to implement its principles.

5 In Fletcher $v$ Fletcher 19481 SA 130 (A), the Appellate Division confirmed that the most important factor to be considered in issues such as custody and access is the best interests of the children and not the rights of parents. See also Bonthuys "Of Biological Bonds, New Fathers and the Best Interests of Children" 1997 SAJHR 623.

6 Act 108 of 1996.

7 Heaton "Some General Remarks on the Concept "Best Interests of the Child" 199053 THRHR 96-97.

8 In terms of $s$ 1(2) of the Children's Act, custody is presently understood as: "[I]n addition to the meaning assigned to the terms 'custody' and 'access' in any law, and the common law, the terms 'custody' and 'access' in any law must be construed as to also mean 'care' and 'contact' as defined in this Act." $\mathrm{S} 1$ of the Act define the terms "care" and "access". "Care" is defined as: "care', in relation to a child, includes, where appropriate - ... (f) guiding, advising and assisting the child in decisions to be taken by the child in a manner appropriate to the child's age, maturity and stage of development; (g) maintaining a sound relationship with the child; (h) accommodating any special needs that the child may have; and (i) generally, ensuring that the best interests of the child is the paramount concern in all matters affecting the child;" and 'contact' as "'contact' in relation to a child means - (a) maintaining a personal relationship with the child; and (b) if the child lives with someone else - (i) communication on a regular basis with the child in person, including - (aa) visiting the child; or (bb) being visited by the ..." 
explore different ways in which children's voices might be heard in family justice system, and how they are heard within the South African system.

\section{WHY INVOLVE CHILDREN IN CUSTODY DECISIONS?}

Historically the courts have respected the rights of parents ${ }^{9}$ to exercise discretion and control relating to activities, welfare, and destinies of their minor children. ${ }^{10}$ Children were deemed incompetent to make decisions as to what is in their own best interest. ${ }^{11}$ Such incapacity has been attributed to lack of intellectual and emotional maturity, lack of experience and a diminished capacity to exercise free will. ${ }^{12}$ An older, less sympathetic attitude towards consulting with children is reflected in Greenshields $v$ Wyllie $^{13}$ wherein Flemming $\mathrm{J}$ held that:

"Court is not inclined to give much weight to the preferences of children of 12 and 14. It is not because what they say is not important but because the Courts know that there is more to it than the way they respond emotionally at this stage. It is therefore not that the court simply ignores their desire, but, as a father sometimes tell a child 'no', the Court as the children's super father, can tell both their father and mother 'no' when it is necessary."

However, the attitude has changed; it is no longer considered that a child is the diminutive of an adult. The child is now generally deemed to be a special human being with particular psychological and biological attributes and is treated as such by the law. ${ }^{14}$ As Michael Freeman formulated it:

"The liberationist movement challenged those who claimed the status of children should be advanced by conferring on children increased protection. The emphasis shifted from protection to autonomy, from nurturance to self determination, from welfare to justice."

There is a growing belief that is important that children as individuals ought to be able to contribute to decisions about their future; this is right based. It is further believed that the wishes and feelings of the child may be

9 In Godbeer $v$ Godbeer 20003 SA 976 (W), the mother wanted to permanently remove her two daughters, aged 14 and almost 12 from South Africa. The Court made its decision solely on the opinion and desires of the custodian parent, the judgement does not contain any mention of the children's wishes.

10 Davies "Access to Justice for Children: The Voice of the Child in Custody and Access disputes" 2004 Canadian Family Law Quarterly 153.

11 See Meggs "Issues in Divorce Mediation Methodology and Ethics" 19934 Australian Dispute Resolution Journal 198 206. The argument was that it was for the parents and not the children to decide what arrangements should be made for the parenting of children.

12 Melton, Koocher and Saks Children's Competence to Consent (1983) 239.

1319894 SA 898 (W) 899 F/G. In this case, preference of two minor children aged 12 and 14 to reside with their father, were not taken into account.

14 Pappas Law and Status of the Child (1983) 349. See also fn 13 above, Meggs summarizes the argument as follows "The main argument in favour of involving children in divorce mediation relies on the belief in children's rights. The children's rights argument implies that children are rational beings who can add and should be invited to make a decision not only between two parents but also about the access arrangements."

15 Freeman The Ideologies of Children's Rights (1992) 3. 
relevant to the effectiveness of the order proposed. ${ }^{16}$ This, in turn, encourages legal policies that extend certain limited adult rights to children, allowing them to exercise some level of personal control in matters of their own welfare, depending on the age and maturity of the child. ${ }^{17}$ In support on involving children, Bernstein maintains that " $\ldots$ the best interests of the child will truly be served when the child is seen as a real person - not a fantasy child, not an idealized child, not a special child, not a commodity - but a child with his own genetics, his own talents, and his own identity". ${ }^{18}$

\section{THE BEST INTERESTS OF THE CHILD AND THE WISHES OF THE CHILD}

Throughout the past two decades, there has been an increasing focus on the legal rights of children. Foremost among these is their right to participate. The statutes of different countries ${ }^{19}$ require the courts to give some consideration to a child's preference when making custody decisions. The Convention on the Rights of the Child ${ }^{20}$ provides that:

"1. States Parties shall assure to the child who is capable of forming his or her own views the right to express those views freely in all matters affecting the child, the views of the child being given due weight in accordance with the age and maturity of the child.

2. For this purpose, the child shall in particular be provided the opportunity to be heard in any judicial and administrative proceedings affecting the child, either directly, or through a representative or an appropriate body, in a manner consistent with the procedural rules of national law."

The Convention considers the importance of considering the opinion of a child when determining their best interests. This will enable the court to know more about the child's needs, difficulties and wishes, the child's personality and the kind of relationship he maintains with each parent. ${ }^{22}$ The crucial provision of the Convention is that the child is a party to any action concerning his parentage. However, there are real and justified fears that it would be harmful or at least hypocritical to involve children in discussions

16 Mitchell Children Act Private Law Proceedings: Handbook (2006) 262.

17 Melton et al 239.

18 Bernstein "Child Protection Mediation: Its Time Has Arrived" 1998-99 16 Canadian Family Law Quarterly 73-119.

19 England, Australia, and most US jurisdictions. In New Zealand, for example, the Child Care Act 2004 places the child's welfare and interest as first and paramount regarding custody decisions.

20 See fn 4 above.

21 See also Article 3 of the European Convention on the Exercise of Children's Rights 1996 (which South Africa has ratified). It provides that a child: "considered by internal law as having sufficient understanding shall in judicial proceedings affecting him be granted and be entitled to request the following rights:

(a) to receive all relevant information;

(b) to be consulted and express his or her own views;

(c) to be informed of the possible consequences of compliance with these views and the possible consequences of any decision."

22 Grosman and Scherman "Argentina: Criteria for Child Custody Decision-making upon Separation and Divorce" 200539 Family Law Quarterly 557. 
when there is little hope that their wishes could be met once voiced. ${ }^{23}$ The other possibility is that, once encouraged to speak out, children might become the targets of parental resentment. ${ }^{24}$

Increasingly children are being treated as active participants in the processes and decisions that affect them. Judges are generally free to determine the appropriate weight to give such preferences, although statutes provide that custodial decisions should be made in consideration with the wishes of the child. Factors that may influence weight to be accorded a child's preference include age and subjective factors such as perceived maturity and capacity to make reasoned decisions, ${ }^{25}$ cognitive and emotional level of functioning, the child's relationship with each parent, and vulnerability to parental pressures. ${ }^{26}$ Children's opinions are therefore taken into account, once they are considered to have sufficient understanding. ${ }^{27}$ In the $M c C a l{ }^{28}$ case, it was held that

"with reference to the child's preference ... if the court is satisfied that the child has the necessary intellectual and emotional maturity to give in his or her expression of a preference a genuine and accurate reflection of his feeling towards and relationship with each of his parents, in other words to make an informed and intelligent judgement, weight should be given to his or her expressed preference".

What should be considered, therefore, is in the best interests of the child. Section 10 of the Children's Act $^{30}$ also provides that

"every child that is of such an age, maturity and stage of development as to be able to participate in any matter concerning that child has the right to participate in an appropriate way and views expressed by the child must be given due consideration".

23 Smart and Neale "It's my Life Too' - Children's Perspectives on Post-Divorce Parenting" 2000 Family Law 163.

24 Ibid.

25 In Van Rooyen $v$ Van Rooyen 19994 SA 435 (C), children's preferences were not taken into account as they were considered not sufficiently emotionally or intellectually mature to express an informed decision.

26 Todres, Wojcik and Revaz The UN Convention on the Rights of the Child: An Analysis of Treaty Provisions and Implications of US Ratification (2006) 138.

27 In Obey $v$ Degling 37 NY2d, 375 NYS2d 91 (1975), it was held that while the court may consider the best wishes of a child, the child's desires are not controlling. It was further held in Cohen $v$ Cohen 70 AD2d 925, 417 NYS2d 755 (1979) that it is not an error to fail to ascertain the wishes of a child of tender years. Both these cases were decided by the Court of Appeals of New York.

28 McCall v McCall 19943 SA $201207 \mathrm{H}$.

29 McCall $v$ McCall supra $207 \mathrm{H}-\mathrm{I}$.

38 of 2005.

31 Similarly, s 31 deals with major decisions involving the child and provides as follows:

"(1)(a) Before a person holding parental responsibilities and rights in respect of a child and takes any decision contemplated in paragraph (b), that person must give due consideration to any views and wishes expressed by the child, bearing in mind the child's age, maturity and stage of development.

(b) a decision referred to in paragraph (a) is any decision -

(i) $\ldots$

(ii) $\ldots$

(iii) $\ldots$ 
It seems according to legislation that the age and maturity ${ }^{32}$ of the child are determining factors in deciding the weight to be accorded to the wishes of the child. ${ }^{33}$

In the case of De Groot $v$ De Groot, ${ }^{34}$ Chetty J provides that

"By all accounts the children are of an age and maturity to fully comprehend the situation and their voices cannot be stifled but must be heard ... I am enjoined by the Act to give due consideration to the views of the children. It appears from all reports that they are of such an age and level of maturity to make an informed decision."

The Children's Act recognizes a child as an individual and a member of a family and a community, with rights and responsibilities appropriate to his or her age and stage of development. The question of custody and access affects the future of the child; it therefore seems logical that the views of children should be considered in these matters. ${ }^{36}$ However, the court should clearly be able to distinguish between those cases in which the children of more mature age have shown decided opinions of their own about where they should live, and those in which one parent is indulging and encouraging them in the role in which they have been cast, as adversaries of the other parent in court battles. ${ }^{37}$

\section{HOW TO HEAR A CHILD'S VOICE}

Article 12 does not outline how a child's voice should be heard in proceedings that affect them ${ }^{38}$ This has led to the difference regarding the methods used by courts in ascertaining children's views. ${ }^{39}$ The question remains whether a child should express his or her view through family reports, ${ }^{40}$ or through the lawyer, or through an interview with the judge in

(iv) which is likely to significantly change or have an adverse effect on, the child's living conditions, education, health, personal relations with a parent or a family member or, generally, the child's well-being."

32 See Grosman and Scherman 200539 Family Law Quarterly 556: "The level of maturity implies that the particular minor has achieved sufficient understanding and intellectual capacity to define his/her needs and wishes and to foresee possible consequences."

33 Keightley Children's Rights (1996) 111.

34 Unreported (ECHC) Case No. 1408/2009, 10 September 2009. The case concerns an application for a variation of the divorce order regarding custody of minor children (triplets, comprising two boys and a girl aged 11, and an older boy aged 14).

35 De Groot $v$ De Groot supra par 17 and 23.

36 Van Zyl Divorce Mediation and the Best Interests of the Child (1997) 35.

37 Stone The Child's Voice in the Court of Law (1981) 176.

Parkinson and Cashmore The Voice of a Child in a Family Law Dispute (2008) 10.

39 Atwood "The Child's Voice in Custody Litigation: An Empirical Survey and Suggestions for Reform” 200345 Arizona Law Review 629.

40 The term "Family Reports" is generic, in South Africa it refers to reports from a child psychologist, social worker or psychiatrist. In North America, such reports are from custody evaluators, whereas in England, such reports are prepared by a Children and Family Reporter whose qualifications include training in child development. See also Douglas, Murch and Perry "Supporting Children When Parents Separate - A Neglected Family Justice or Mental Health Issues? 19968 Child and Family Law Quarterly 137-158. 
chambers, ${ }^{41}$ or directly in the courtroom. ${ }^{42}$ This has led to considerable variation in different countries and jurisdictions in practical mechanisms to incorporate the article in their own legislation ${ }^{43}$ "and in guidelines for practice and how they have met their obligations under this international treaty". ${ }^{44}$

\section{Family reports}

The involvement of a social science-trained professional is the most common way in which children's voices are heard in custody proceedings. ${ }^{45}$ The practice in South Africa is to involve the office of the Family Advocate ${ }^{46}$ in disputes regarding custody. The Family Advocate plays a role in a ascertaining the views of the child, and presenting evidence of a child's views to the court. ${ }^{47}$ Nicholson CJ supports the practice of using a court appointed expert to ascertain the views of the child. He commented:

"The children will be interviewed and may be asked their preferences about their future living arrangements, but the report writers are skilled social workers or psychologists who are aware of the dangers associated with their responses. They may reflect parental pressure, loyalty to one or other, or a bald description of what a child said and may result in a breakdown of in a relationship with the non-preferred parent, or some form of reprisal. The skills of the report writer are to convey to the Court the child's wishes in a context of the circumstances in which the interview took place, including observations of intonations, body language and the like."

41 "Interview in Chambers" refers to an interview that is conducted outside the Courtroom.

42 Taylor, Tapp and Henaghan "Respecting Children's Participation in Family Law Proceedings" 200715 International Journal of Childrens Rights 61-82.

43 Article 44 of the CRC obligates signatory states to incorporate a children's rights perspective into their laws, including their family and juvenile law systems, and signatory states must regularly review their laws and practices to maintain compliance with the CRC. The article requires states to submit reports within two years of ratifying the Convention, and very five years thereafter.

44 Parkinson and Cashmore "Judicial Conversations with Children in Parenting Disputes: The View of Australian Judges" 2007 21(2) International Journal of Law, Policy and the Family 160-189.

45 Parkinson and Cashmore 47.

46 This office was created by the Mediation in Certain Divorce Matters Act, 1987. The Act provides for the powers and duties of the Family Advocate to institute an enquiry to enable him to furnish the court with recommendations on any matter concerning the welfare of minors involved in divorce or related proceedings or on such matters as they are referred to him by the court.

47 Schaffer The Law of Access to Children (2007) 102. This is the normal practice in most common law jurisdictions. Australia and New Zealand use the services of a trained counsellor, whereas US involves a custody evaluator.

48 Nicholson "Children and Children's Rights in the context of Family Law" Speech to the Law Asia Conference 2003 Brisbane, Australia. See also Abella "Procedural Aspects of arrangements For Children Upon Divorce in Canada" 198361 Canadian Bar Review 46: "Since the test in custody is "best interests" and since the evidence required must necessarily go beyond materially demonstrable perceptions, it is difficult to see how informed judgments can be made about the best interests of children without at least the assistance of a non-partisan expert who can better attempt to evaluate the competing emotional claims that underlie the pursuit of legal remedies." 
Doogue $\mathrm{J}^{49}$ (Family Court of New Zealand) supports the practice of obtaining a child's views via the expert, especially where the child is too young to speak, has a disability or has been subjected to trauma or pressure within their family. ${ }^{50}$ She writes:

"I consider any step back from a multi-disciplinary approach would be a retrograde step because such an approach maintains the requisite flexibility to respond to individual children having regard to their age, gender, ethnicity, culture, personality, cognitive development and verbal capacity. It also takes into account the extent to which they have been subject (including alienation and trauma), and any special psychological, educational or medical needs that the child has, e.g. suicidality, depression, conduct problems, any trauma history of the child. Finally if the child has expressed the desire to express their views to a particular person in the Family Court team such as a Judge this can be respected if we do not have a formulaic approach."

The expert evidence from a child's perspective will be tested rigorously to ensure that the court is well placed to make the decision of what is best for the particular child.

It is not in dispute that the professionals who are involved in family disputes play an important role as advisers and gatekeepers, with judges as adjudicators. Though information may be garnered from different sources including the reports of the child psychologists, and social worker's reports, there are unfortunately no guarantees that whoever determines what will be in the child's best interest will come up with the right decision. This was confirmed by Chetty J. He described one of the expert witnesses as a "poor witness" who was evasive, unable to answer questions directly and reluctant to make obvious concessions:

The defensive attitude which she displayed towards her report compounded the problems she experienced under cross examination and contributed markedly to her unease in the witness box ... it became obvious that her recommendation was inextricably bound to her diagnosis. She was reluctant to concede that even if the factual substratum upon which her diagnosis rested was different to that which she accepted her conclusion could be different ... Cross examination soon established the spurious nature of the allegations emanated from the [appellant] and those loyal to him which she unreservedly accepted as factually correct."

One matter is clear as a matter of principle. The recommendations from the reports produced by the Family Advocate do not bind the court. ${ }^{52}$ In Stock $v$ Stock, ${ }^{53}$ Diemont $\mathrm{J}$ held that:

49 Doogue "A Seismic Shift or a Minor Realignment? A View from the Bench on Ascertaining Children's Views" Paper presented at the Child Law Conference 25 May 2006 Auckland.

50 Taylor et al 200715 International Journal of Childrens Rights 61-82.

51 Potgieter $v$ Potgieter 20073 All SA 9 (SCA).

52 Potgieter $v$ Potgieter supra par [16]. Chetty J pointed out that "It is clear that ... that expert opinion is not the mere conjecture, surmise or speculation of the expert, that whilst in many cases a court needs and benefits from an expert's opinion, the expert witness should not usurp the function of the court." See also Whitehead v Whitehead 19933 SA 72 SE paragraph $\mathrm{J}$ where Burger AJ clarifies the duty of the Family Advocate. He writes "The function of the Family advocate in an action for divorce in which the custody of minor children is in the issue and the matter has been referred to the Family advocate, is to be of assistance to the court by placing facts and considerations before the court. The Family Advocate should make a balanced recommendation and should not take sides against one 
"An expert in the field of psychology or psychiatry who is asked to testify in a case of this nature, a case in which difficult emotional, intellectual and psychological problems arise within the family, must be made to understand that he is to assist the court. If he is to be helpful, he must be neutral. The evidence of such a witness is of little value where he, or she, is partisan and consistently asserts the cause of the party who call him. I may add that when it comes to assessing the credibility of such a witness, this Court can test his reasoning and is accordingly to that extent in as good a position as the trial Court was."

However, in some cases the strength of the reports may be such as to determine the matter effectively.

\section{Judicial interview}

Some researchers are of the view that "talking to a child can allow the judge to gain an impression of the child's maturity, a factor to be considered in deciding the weight to be given to a child's views". ${ }^{44}$ Huddard and Ensminger ${ }^{55}$ argue that:

"The child's statement of her views to the judge directly will probably be the most reliable evidence for a court. The judge can observe the child and assess her competency, understanding of the situation, and possible influence, without the screen of a third party."

South African legislation directs judges to give consideration to the wishes of the child, but it does not require judges to interview children in chambers to determine those wishes. ${ }^{56}$ In Australia, England, and most US jurisdiction, the practice for a judge to interview a child directly in chambers ${ }^{57}$ is used. However, the most preferred is the indirect method of informing the court of children's views through family reports. ${ }^{58}$ Three Canadian judges, Abella, Heureux-Dubé and Rothman, ${ }^{59}$ have indicated that they consider the practice of judicial interviewing undesirable, and should be used only as the last resort in ascertaining the child's wishes. They explained:

"The practice of interviewing children in chambers is not the ideal way to ascertain a child's wishes. The interview is conducted in an intimidating environment by a person unskilled in asking questions and interpreting the answers of children. In the relatively short time these interviews take, it is difficult to investigate with sufficient depth and subtlety those perceptions of a child which explain, justify or represent the child's views. Moreover, the interview may be perceived as a violation of the judge's role as an impartial trier of fact who does not enter the adversarial arena. The impartiality may

party in favour of the other. Furthermore, the Family Advocate ought not to create the impression that he or she has taken a decision and wishes to prescribe to the court." 19813 SA 1280 (A) 1296E/F.

54 Cashmore and Parkinson "What responsibility Do Courts have to Hear Children's Voices?" 200715 International Journal of Childrens Rights 49.

55 Huddart and Ensminger Hearing the Voice of Children (1992) 8.

56 Atwood 200345 Arizona Law Review 629.

57 Parkinson and Cashmore 2007 21(2) International Journal of Law, Policy and the Family 160-189.

58 Cashmore and Parkinson 200015 International Journal of Childrens Rights 49.

59 Abella and Heureux-Dubé Family Law, Dimensions of Justice (1983) 329. 
also be compromised by the judge assuming the role of inquisitor in questioning children.

Another argument against judicial interview is that judges are not better qualified to interpret children's views in the light of all the circumstances. ${ }^{61}$ The accepted view in most modern common law jurisdictions ${ }^{62}$ is that the "contemporary understanding of children's psychological, emotional and cognitive development should inform the ways in which judges elicit and evaluate children's perspectives". ${ }^{63}$ Ideally, it is better to rely on the people who are skilled to elicit the child's views and to interpret their wishes and feelings to the court. ${ }^{64}$

\section{Children as witnesses in the courtroom}

South Africa and most common law jurisdictions have taken a strong protective stance and consider it unfair on children to be dragged into the arena as witnesses, and asked to choose between the two parents, both of whom they love. ${ }^{65}$ This is the reason why they are often not involved. Another area of concern has been expressed regarding the adversarial nature of the proceedings where children will be subjected to the rigours of cross-examination, and the intimidating atmosphere of the courtroom. ${ }^{66}$ Huddart and Ensminger, however, support the view that children should be called regularly as witnesses in family law cases. They argue that:

"If those views are expressed in the courtroom, the parents will be forced to listen to, if not hear, their child. The child will know that his views are being stated as clearly as she can formulate them, in language she chooses as appropriate to be heard by her parents, without any danger of being misstated by a well-meaning adult".

The counter-argument against the statement is that children find the experience of having to testify in the company of parents very stressful,

60 See also Kelly "Psychological and Legal interventions for Parents and Children in Custody and Access Disputes: Current research and Practice" 200210 Virginia Journal of Social Policy and Law 154. Kelly questions the competency of judges in interviewing and assessing children's views. She writes "Judges are not trained in child interviewing skills, and generally lack knowledge about developmental differences in cognitive, language and emotional capacities. Thus, it is hard for even the most experienced judge to place children's responses in appropriate context and evaluate the weight that should be given to their wishes."

61 Parkinson and Cashmore 48. See also Bala, Talwar and Harris "The Voice of Children in Canadian Family law Cases" 200524 Canadia Family Law Quarterly 228: "There is a need for anyone interviewing a child about the sensitive issues that rise in family law to have the "training and time to establish a rapport with the child and to gain a genuine understanding of the child's wishes and perceptions."

Parkinson and Cashmore 55.

63 Atwood 200345 Arizona Law Review 674.

64 Ibid.

65 Cashmore and Parkinson 200015 International Journal of Childrens Rights 49.

66 Rhonda "The Voice of the Child in Divorce, Custody and Access Proceedings" 2002 Family, Children and Youth Section, Department of Justice Canada 1E.

67 Huddart and Ensminger 8. 
especially those in which the parents take bitterly opposing positions. ${ }^{68}$ Such may implicitly, if not explicitly, affect the unsuccessful parent's attitude or conduct towards the child.

\section{WHICH CHILDREN'S WISHES SHOULD BE SOUGHT?}

Though the Convention acknowledges that the views of the child should be considered and be given due weight, it does not establish a specific age at which a child can begin expressing his or her views freely. ${ }^{69}$ It therefore extends to any child who has a view on a matter that concerns him or her, considering the maturity and understanding of the particular child. ${ }^{70} \operatorname{In} / \mathrm{V} S^{71}$ Erasmus AJ held that:

"The relevant children appeared to be sufficiently mature and old enough to give independent opinion as to their refusal to have contact with the father, and their wishes in this regard had to be respected."

The question of how to assess if the child "is of such an age, maturity and stage of development", or the kind of weight to be given to the expressed views and wishes of the child still raises questions which as yet do not have satisfactory answers. ${ }^{72}$

Courts are often in a dilemma of deciding when, or whether, it is appropriate to allow the children to have a real say in what will happen to them, and whether they should respond to those wishes or not. In answering the question regarding the age or stage where a child's wishes should be heard, Nasmith ${ }^{73}$ argues:

"err on the side of the inclusion rather than exclusion of the children's views and preferences. I wonder what is gained by arbitrarily defining areas for excluding children's preferences. We may be falling back into some of the historical traps set for children. What harm can it do to bring preferences forward even if their weight turns out to be relatively slight? What is the fear?

The evidence is going to be weighed in the end along with other factors. The child's preference is not necessarily determinative. It is part of the evidence".

The counter-argument may be that it just amounts to window dressing to tell the child that he will be consulted whilst knowing that his preferences may not be considered. In addition, children may resent their participation in the process.

68 Cleland and Sutherland Children's Rights in Scotland (2009) 36. See also Bala et al 2005 24 Canadian Family Law Quarterly 278. They maintain that children may be reluctant to express their views openly for fear of causing emotional pain to one or both parents.

69 Other states' statutes, eg. Texas Family Code (2003) as amended identify the age at which courts must give children's wishes greater weight, while still retaining discretion to depart from those wishes. See s 159.000 of Code (2009), where children of twelve and older are allowed to choose the custodian through an interview with the judge in chambers.

70 Mitchell Adoption and Special guardianship: A Permanency Handbook (2009) 187.

7120002 SA 993 (C) 997F-H.

72 Eekelaar "The Importance of Thinking that Children have Rights" 19926 International Journal of Law and the Family 230-231.

73 "The Inchoate Voice" 19928 Canadian Family Law Quarterly 4354. 


\section{WHAT WEIGHT SHOULD BE ATTACHED TO CHILDREN'S PREFERENCES?}

In Re T (Abduction: Child's Objection to Return), ${ }^{74}$ the United Kingdom case brought under the Hague Convention on the Civil Aspects of International Child Abduction, the Court of Appeal gave guidance on the weight to be accorded to a child's wishes:

"It seems to me [said Thorpe LJ] that the matters to establish are: (1) Whether the child objects [to a particular course of conduct]. (2) The age and degree of maturity of the child. Is the child more mature or less mature than or as mature as her chronological age? ... (3) ... the strength and the validity of those views [need to be ascertained] which will call for an examination of the following matters among others: (a) What is the child's own perspective of what is in her interest, short, medium and long-term? Self-perception is important because it is her views which have to be judged appropriate. (b) To what extent, if at all, are the reasons for objection rooted in reality or might reasonably appear to the child to be so grounded? (c) To what extent have those views been shaped or even coloured by undue influence and pressure, directly or indirectly exerted by the abducting party? (d) To what extent will the objections be mollified on return and, where it is the case on removal from any pernicious influence from the abducting parent?"

Though the Convention acknowledges that a child can do and form views from an early age, it places its reliance on parents, and family members where appropriate, to give appropriate direction, advice and guidance to that child. ${ }^{75}$ However, the Convention does not provide for assistance in care or custody issues; these are due to the fact that children can be manipulated by adult agendas. Though both the Children's Act and the Convention do not provide guidelines on the weight to be accorded to a child's wishes, the court as the upper guardian of all minors is entitled to exercise its own discretion. In $P \vee P,{ }^{76}$ Chetty $\mathrm{J}$ said:

"Determining what custody arrangement will serve the best interests of the children in any particular case involves the High Court making a value judgment, based on its findings of fact, in the exercise of its inherent jurisdiction as the upper guardian of the minor children."

74 [2002] 2 Fam. LR 192 per Ward LJ 203. See also H v H (1995) F.L.C. $92-598$ (Full Court of the Family Court of Australia) per Baker J: "As a matter of practical day-to-day experience, the problem in this area usually relates to the ascertainment of the wishes of the child and their interpretation and assessment in the face of conflicting evidence. Against that background, the court will attach varying degrees of weight to a child's stated wishes depending, upon amongst other factors, the strength and duration of their wishes, their basis and the maturity of the child, including the degree of appreciation by the child of the factors involved in the issue before the court and their longer term implications. Ultimately, the overall welfare of the child is the determinant ... The application of that principle will be influenced by the social background of the times and ... it appears to us the recent social forces have indicated that more realistic weight should be attached to the wishes of the children than may have been the practical realities in the years past."

75 Article 5 of the Convention explicitly articulates this theme. It provides: "States parties shall respect the responsibilities, rights and duties of parents, or where applicable ... other persons legally responsible for the child, to provide in a manner consistent with the evolving capacities of the child, appropriate direction and guidance in the exercise by the child of the rights recognized in the present Convention."

7620073 All SA 9 (SCA). 
Children should be able to express their views and opinion freely and have them treated with respect in terms of the Convention. Though one child's views and interests in a particular case may be different from the sibling, that does not mean that the other one's expressed views are invaluable. A child as an interested party must be given an opportunity and space to make his or her own views known. Like adults, children have different levels of competence in different parts of their lives. This was affirmed by Ngcobo J:

"What must be stressed here is that every child is unique and has his or her
own individual dignity, special needs and interests. And a child has a right to
be treated with dignity and compassion. This means that the child must be
'treated in a caring and sensitive manner.' This requires 'taking into account
[the child's] personal situation, and immediate needs, age, gender, disability
and level of maturity'. In short, [e]very child should be treated as an individual
with his or her own individual needs, wishes and feelings."77

The above thoughts were affirmed by Sachs $\mathrm{J}$ in the case of $S \vee M:^{78}$

"A truly principled child-centred approach requires a close and individualised examination of the precise real-life situation of the particular child involved. To apply a predetermined formula for the sake of certainty, irrespective of the circumstances, would in fact be contrary to the best interests of the child concerned."

This decision speaks to the point that even if a child is not considered to have a clear preference about custody, the child may have perspectives about family relations that may assist the court in its decision-making ${ }^{79}$ The child's view must be assessed with the other factors the court must consider in resolving custody issues.

Legislation stresses the importance of listening to the wishes of the child. The authorities, however, have a duty to act in the best interests of the child, which may mean contradicting the child's wishes. In the case of Soller No $v$ Another $^{80}$ an application was brought on behalf of the 15-year-old son to vary an order granted at the time of divorce which gave custody of the minor child to the mother. The child's wish to reside with the father was provisionally granted subject to custody remaining with the mother. The child's expressed view to live with the father became the dominant factor, not the persuasive one. ${ }^{81}$

77 Director for Public Prosecutions, Transvaal v Minister for Justice and Constitutional Development, Albert Phaswane and Aaaron Mokoena (Centre for Child Law, Childline South Africa, RAPCAN, Children First, Operation Bobbi Bear, POWA and Cape Mental Health Society as Amici Curiae [2009] ZACC 8 par 123 (unreported).

78 S v M (Centre for Child Law as Amicus Curiae) [2007] ZACC 18; 20083 SA 232 C; 200712 $B C L R 1312$ [CC] par 24. In this case, the Constitutional Court ruled that the courts should always consider the child's best interests before imposing a jail sentence on the parent or primary caregiver

79 Bala et al 200524 Canadian Family Law Quarterly 224.

8020035 SA $430(\mathrm{~W})$

81 See also Lubbe $v$ Du Plessis 20014 SA 57 (C). Three sons, Bernard aged 10 and 4 months, Jacques aged 8 and 4 months and Lawrence who had just turned six, preferred to reside with their father. Weight was attached to their preferences. 
An argument may be that the court in this case failed to take into account the long-term interests of the child. Instead, the judge placed more emphasis on the child's short-term interests. However, the child had a strong preference to live with the father and the court did not want to impose their own view because they believed that was what was best for the child.

The Canadian case of Strangle $v$ Strangle ${ }^{82}$ concerned the weight to be given to the wishes of a 13 year-old boy in a custody dispute between his parents, centred particularly around his education. In this case the parties agreed on joint custody with "primary physical placement" to the mother's child. Mr Strangle sought an order to live with the child. A letter from the boy's psychologist was provided to the court in support of the application.

In this case, Mr Justice McEwan held that:

"Given the context in which Charlie's choice was made, and bearing in mind his age and maturity, I am not satisfied that it ought to be accorded weight sufficient to displace what is otherwise a case in which Charlie's best interests lie in staying with his mother."

It appears that there is no specific age at which a child's wishes are given greater credence or weight. The preference of a child is therefore not a determining factor, it is a matter of discretion as to whether or not the court takes the views of the child into account. The court is not bound by the preference of the child where it appears that the best interests of the child lie elsewhere.

The court must take into account what is in the best interests of the child, and in doing so, must also consider certain contextual matters, including the age and maturity of the child, the child's familiarity with the issue and his or her ability to articulate the issue as well as his/her other wishes, and the child's interaction with one or both parents, to name but a few. ${ }^{83}$ In Meyer $v$ Gerber $^{84}$ Lombard $\mathrm{J}$ attached due weight to the child's preference and choice:

" $\mathrm{B}$ (the child) made a decision and had persisted therein. He had addressed a letter about the decision to the Respondent and he had also deposed to two affidavits which had been included in the papers. It could be accepted that the letter had been B's own brainchild and that he had neither been assisted nor influenced by the applicant to write it."

In this decision, the child was considered to have made a calculated and intelligent decision, through his endowment with enough intellectual and emotional maturity.

\footnotetext{
2002 B.C.S.C. 3825 March 2002.

83 Taylor "When are Children's Views Determinative in Relation to Matters of Custody?" 2002 The Scrivener 54-59.

841999 3 SA 650 (O) 656G/H. This case concerns a 15-year-old son who made a decision that he wished to reside with the father (Applicant) instead of the Respondent. The Respondent's contention that the child is immature to make a decision was not considered by the court.
} 


\section{$7 \quad$ CONCLUSION}

Hearing the wishes and the experiences of children in custody matters is a very important part of determining their best interests. There seems to be an increasing acceptance in many jurisdictions that decisions that are made about children's futures, should be made in consultation with children themselves, for they are the ones who have to live with those decisions. Involving children also gives them a much greater sense that they have a say in their lives and a freedom to contribute to the decisions that affect their lives. It is therefore important that children should be educated about their rights, and encouraged to exercise them in every aspect of their lives.

However, children may be deeply affected by the insensitivity of the methods that are used in involving them, as well as the outcomes that are achieved through negotiations, ${ }^{85}$ or imposed by the judge. Children's involvement must be in a sensitive fashion, one that takes account of such factors as the degree of conflict, and the clarity or ambiguity of the child's preferences. ${ }^{86}$ The decision whether or not to express his or her feelings should entirely be the child's choice, and he or she should not be pressured or manipulated. ${ }^{87}$

Although the $C R C$ requires that those children capable of expressing their own views should be heard, there is no duty under the Convention where a decision-maker determines that the child cannot do this. ${ }^{88}$ The interests of children should not be "conceptualised in terms of parental interests". ${ }^{89}$ The courts should therefore investigate carefully where the interests of the child are involved.

Further, though a number of statutes provides that children should be asked for their views by those making decisions about their lives, the child's perspective should not be a decisive factor, but it should be considered seriously and given due weight according to the age and maturity of the child. ${ }^{90}$ The latter stem from the fact that a child's expressed preference can be unreliable, short-sighted, or even sometimes irrational. ${ }^{91}$ The approach that the courts use towards the best interests of the child should always remain flexible, as different approaches will be emphasised in different situations and at different times. From the international perspective, however, it remains that different countries and cultures may retain different perspectives about what a child's best interests may be.

\footnotetext{
Bala et al 200524 Canadian Family Law Quarterly 224.

Ibid.

Ang, Berghmans, Cattrijsse, Delens-Ravier, Delplace, Staelens, Vandewiele, Vandresse and Verheyde Participation Rights of Children (2006) 232.

88 Pappas Law and Status of the Child (1983) 165.

89 Bonthuys "Epistomological Envy: Legal and Psychological Discourses in Child Custody Evaluations" 2001118 SALJ 329-346.

90 Grosman and Scherman 200539 Family Law Quarterly 557.

91 Todres et al 139.
} 